\title{
DIE BELYDENDE KRING EN ABRECSA EN HULLE INVLOED OP KERKLIKE VERHOUDINGE IN SUID-AFRIKA
}

D CRAFFORD

Op 19 en 20 Mei 1975 het 'n groep predikante van die NGKA en NGSK in Bloemfontein vergader en besluite geneem oor kerkvereniging in die familie van NG Kerke. Die organiseerders het die byeenkoms aangekondig as die "eerste Algemene Sinode van die Susterskerke". Die vergadering was ook bedoel om 'n strategie van optrede uit te werk vir die komende Algemene Sinode van die NGKA. Die vergadering het die organiese vereniging van die NG Kerke aanbeveel maar dan op voorwaarde dat die verenigde kerk apartheid (afsonderlike ontwikkeling) sal verwerp as ' $n$ dwaling en ' $n$ sonde.

Uit hierdie kring van leraars is die Broederkring gebore met wit en swart lede uit die NGKA, NGSK en RCA. Die lede moes natuurlik bogenoemde ideale steun.

Die Algemene Sinode van die NGKA van Junie 1975 het die optrede van sy leraars in hierdie verband veroordeel. Die besluit lui: "Die Algemene Sinode spreek sy afkeur uit oor die aandeel wat broeders uit die NGKA gehad het aan die sake in verband met die vergadering van die sogenaamde 'Eerste Algemene Vergadering van die Susterskerke' in Bloemfontein en vra hulle om in die toekoms versigtiger te wees". ${ }^{1}$

Die Algemene Sinode van die NGKA het nietemin by dieselfde Sinode besluit om te werk in die rigting van vereniging met die NGK, die NGSK en die RCA. Die Sinodes van die NGSK (1978) en die RCA (1976) het ook alreeds soortgelyke besluite geneem. In teenstelling hiermee het die Algemene Sinode van die NGK in 1978 die versoek van die Federale Raad van NG Kerke vir 'n oorkoepelende Sinode afgestem en die bestaande Federale Raad as voldoende uitdrukking van eenheid beskou.

Oor die kwessie van organiese kerkvereniging is daar dus eenstemmigheid by die genoemde lede van die NG Kerkfamilie. Oor die wyse waarop die kerkvereniging moet plaasvind, is daar egter verskil van mening. Die Broederkring se opvatting was dat daar op elke moontlike wyse druk op die NGK uitgeoefen moet word om apartheid as kettery te verwerp ten einde op dié grondslag die kerke te verenig. (Hierdie aandrang moet sekerlik ook gesien word teen die agtergrond van die besef dat so 'n uitspraak van die NGK 'n groot bydrae tot politieke koers- 
wysiging sou kon lewer.) Die NGKA se amptelike standpunt was egter eerder dat so ' $n$ kerkvereniging langs die weg van onderhandeling en konsensus bereik moes word. Die Sinode van Barkley-Wes (1983) het besluit dat kerkvereniging nie sonder medewerking van die NGK kan plaasvind nie. Daarteenoor het die NGSK by sy Sinode van Belhar besluit om van die NGK 'n skuldbelydenis te eis. Die RCA is ook in twee kampe verdeel oor die kwessie van kerkvereniging. Die Broederkring was 'n belangrike faktor om hierdie groeiende polarisasie binne die NG Kerke op die spits te dryf.

\section{Die rol van die Belydende Kring van NG Kerke}

By die jaarvergadering van 1984 het die Broederkring sy naam verander na die Belydende Kring van NG Kerke. Die gedagte hieragter is dat die Christene wat apartheid verwerp 'n belydende kring van ware Christene vorm teenoor dié in die kerke wat die valse kettery van apartheid aanhang. Die Belydende Kring moet dus die kern vorm van die toekomstige verenigde NG Kerke wat apartheid as kettery verwerp. Op dié wyse het die Belydende Kring die verwerping van apartheid as kettery en soos ons later sal sien, die verklaring van Ottowa oor apartheid, as toetssteen verhef vir ' $n$ ware christelike geloof. In die neiging van die verheffing van een christelike leerstuk tot absolute norm vir optrede openbaar die Belydende Kring bepaald sektariese neigings. 'n Mens kan egter goed begryp waarom hierdie aangeleentheid Swart Christene diep in die hart aangryp en waarom dit vir hulle so 'n belangrike aangeleentheid is.

Die Belydende Kring se onvermoeide stryd teen apartheid is op twee fronte gevoer. In die binneland is lede gewerf en vergaderings gehou met die doel om die Sinodes van die NGSK, NGKA en RCA so veel moontlik te beïnvloed om apartheid as kettery en sonde te verwerp en om druk op die NGK uit te oefen om dieselfde te doen. Hierdie optrede het 'n groeiende polarisasie veroorsaak tussen gematigde kerkleiers wat vir gesprek en onderhandeling te vinde was en die lede van die Belydende Kring wat druk, boikotte van samesprekings en dwangmaatreëls voorgestaan het.

As mens eenmaal die koers ingeslaan het om mense deur druk en dwang te oortuig, moet jy natuurlik voortgaan om die skroef aan te draai indien die gewensde resultate nie verkry word nie. Dit verklaar ook waarom lede van die Belydende Kring in Ottowa tydens die vergadering van die Wêreldbond van Gereformeerde Kerke by die Nagmaalsviering uitgestap het uit protes teen die geslotenheid van die Nagmaal in sekere Suid-Afrikaanse Gereformeerde Kerke. Die Belydende Kring se tweede front van aanval was dus om by buitelandse kerke steun te werf vir hulle 
veldtog teen apartheid. In die proses het hulle deurgaans gepleit vir'n groter isolasie van die NGK ten einde hom tot ander insigte te dwing. Die Belydende Kring het kontakte en gesprekke aangeknoop met Gereformeerde Kerke en groeperinge in Nederland, Switserland, Duitsland, Engeland, Skotland, die VSA en Kanada en deurgaans gepleit vir groter druk op die NGK. In die proses is ' $n$ karikatuur van die NGK opgebou en aan buitelandse kerke voorgehou. Die NGK is voorgestel as uitvinder en argitek van apartheid en as die liggaam wat ideologiese en teologiese fundering vir die onderdrukkende beleid verskaf het. Die NGK moes dus grootliks vader staan vir die lyding wat Swartmense onder die stelsel moes verduur. Niemand kan ontken dat lidmate, ampsdraers en sinodes van die NGK in die vyftiger en sestigerjare die beleid van afsonderlike ontwikkeling openlik ondersteun het nie. Maar dan was dit in die idealistiese vorm van totale gebiedskeiding tussen volkere en met die motief dat juis op hierdie wyse die grootste mate van geregtigheid en voorspoed aan almal moet geskied. Vandag kan 'n mens maklik sê dat dit 'n oordeelsfout was en dat so ' $n$ beleid nooit kon realiseer nie. Die voorstanders daarvan het egter meesal eerlik daarna gestrewe om geregtigheid aan almal op dié wyse te laat geskied. Om egter te beweer dat die NGK op enige wyse onderdrukking, vernedering of verarming van mense op die oog gehad het, is om 'n karikatuur van die Kerk en sy leer en optrede te maak. Dit is presies wat die Belydende Kring in sy skakeling met buitelandse kerke gedoen het. Deurgaans is daarop aangedring dat die kerke hulle gesprek en skakeling met die NGK wat voorgestel is as die draak van Openb. 13, moet afbreek. Die Belydende Kring beroem homself dan ook daarop dat hy die besluit van Ottowa voorberei het deur sy kontakte met Gereformeerde Kerke in die buiteland.

'n Mens wil hiermee hoegenaamd nie ontken dat die NGK in sy standpunte en optrede van die verlede gefouteer het nie. Daar is baie om skuld oor te bely en daarop kom ons later weer terug. Die karikatuur wat egter van die kerk geteken is as die groot monster van dwaling en kettery en selfs afgodediens is nie geregverdig nie. As iemand homself hoegenaamd nie erken in 'n prentjie wat geteken word nie, sal dit hom sekerlik nie bring tot berou en skuldbelydenis nie.

Die suksesse van die Belydende Kring in die binneland was van wisselende aard. By die jaarvergadering in Desember 1982 te Kraaifontein in die Kaap was daar 100 afgevaardigdes. Ds. Elia M. Tema van die NGKA is as voorsitter verkies en mnr. Shun Govender is aangestel as voltydse Algemene Sekretaris. Ds. Lukas Mabusela van die NGKA is benoem as organiserende sekretaris. Die Belydende Kring het sukses behaal om fondse uit die buiteland te verkry asook beurse vir sy lede om veral in Nederland te gaan studeer. Hulle het deurgaans die raad en ad- 
vies van eers die Christelike Instituut en later die Gereformeerde Kerke in Nederland en elders tot hulle beskikking gehad.

Die Belydende Kring het ook invloed probeer uitoefen in die Kopano ya Baruti le Baboledi (KBB) wat 'n vereniging is van Swart leraars en evangeliste van die NGKA in Transvaal en die OVS. In sekere streke het vergaderings van die Belydende Kring die van die KBB geheel en al vervang. Elders is invloed uitgeoefen op die besluite van die KBB. So het ' $n$ vergadering van die KBB in September 1982 in Springs byvoorbeeld die resolusies van Ottowa teen die NGK ondersteun, terwyl die Algemene Sinode van die NGKA in 1983 dit afgewys het. Die optrede van lede van die Belydende Kring het gelei tot 'n breuk in die RCA wat nog nie herstel kon word nie en wat dit moeilik maak vir dié kerk om 'n sinode byeen te roep.

Wat die buitelandse kerke betref, was die suksesse van die Belydende Kring nog groter en het dit uitgeloop op die resolusie van Ottowa wat op 26 Augustus 1982 deur die Wêreldbond van Gereformeerde Kerke aanvaar is en soos volg lui:

"We declare with Black Reformed Christians of South Africa that apartheid ('separate development') is a sin, and that the moral and theological justification of it is a travesty of the Gospel, and in its persistent disobedience to the Word of God, a theological heresy".

Op grond van die feit dat die NGK morele en teologiese regverdiging sou verkry vir bogenoemde dwaalleer en omdat die kerk dit nie openlik verwerp nie, is die NGK uit die Wêreldbond geskors tot tyd en wyl hy tot ander insigte kom, sy skuld bely en alles in sy vermoë doen om apartheid te bestry in kerk en in politiek.

In 'n stuk getiteld "Implication of the Ottowa Resolution of the WARC" het die Belydende Kring die implikasies van dié resolusie vir die NG Kerkfamilie getrek.

Hiervolgens sou 'n verwerping van die Ottowa-resolusie vir die NGK die volgende implikasies hê:

1. verdere verslegting van die reeds gespanne verhoudinge met die orige lede van die NG Kerkfamilie;

2. dit feitlik onmoontlik maak om voort te gaan met sendingwerk onder Swartmense in Afrika; en

3. die kerk homself in groter isolasie dompel ten opsigte van Gereformeerde Kerke in Suid-Afrika en in die res van die wêreld. 
Die gekleurde Ned. Geref. Kerke sal ook in die lig van die Ottowabesluite hulle verhouding met die NGK in heroorweging moet neem aangesien die kerk nou aan kettery skuldig bevind is. Die vraag word gevra of die dogterkerke nog teologiese opleiding vir hulle leraars moet aanvaar van dosente wat lid is van die NGK; of hulle nog finansiële steun van die NGK kan aanvaar en ten slotte of hulle nog in offisiële vergaderings met die NGK sal kan saamwerk?

Vir ander kerke in Suid-Afrika het dit die implikasie dat hulle nie met die NGK mag saamwerk of gesprekke mag voer voordat dié kerk nie beantwoord aan die eise wat deur Ottowa gestel is nie. Dit geld ook vir kerke buite Suid-Afrika.

Vir lidmate van die NGK wat we! die resolusies van Ottowa onderskryf, is daar volgens die Belydende Kring ten minste vier opsies oop:

1. inulle kan in die kerk bly as gefrustreerde, ontevrede lidmate;

2. hulle kan saamgroepeer in die kerk en belydende groepe vorm wat die kerk van binne uit wil hervorm;

3. hulle kan die kerk bedank en by een van die gekleurde NG Kerke aansluit; of

4. hulle kan werk in die rigting van die stigting van 'n veelrassige Gereformeerde kerk en solank begin om Bybelstudiegeleenthede en gemengde eredienste te organiseer.

Die Belydende Kring stel hulleself dit dus ten doel om te bewys dat apartheid ' $n$ rassistiese ideologie is wat boonop gegrond is in ' $n$ valse teologie wat die mees fundamentele waarhede van die evangelie verontagsaam. Die organisasie wil verder die drie gekleurde NG Kerke bevry van dominering deur die NGK sodat hulle duidelik ' $n$ eie stem kan laat hoor. Daar moet ernstig gepoog word om kerkvereniging tussen die drie kerke te bewerkstellig en daarnaas ook te poog om alle Gereformeerde Kerke in die land wat Ottowa onderskryf, te verenig in een veelrassige kerk. Ten slotte wil die Belydende Kring bevrydingsteologie uitbou as 'n teologie van reformasie en vernuwing op grond waarvan 'n nuwe eenheid onder Gereformeerde Kerke gebou kan word.

Die eerste stap op pad na die bereiking van laasgenoemde ideaal was die stigting van die Alliance of Black Reformed Christians in South Africa (ABRECSA).

\section{Stigting en doelstellings van ABRECSA}

Die stigtingsvergadering het plaasgevind vanaf 26 tot 30 Oktober 1981 te 
Hammanskraal. Ongeveer 60 deelnemers komende uit agt Gereformeerde Kerke in Suid-Afrika het die vergadering bygewoon. Die doel van die vergadering was voorbereiding vir die vergadering van die Wêreldbond van Gereformeerde Kerke te Ottowa in 1982 asook die stigting van ' $\mathrm{Al}$ liansie van Swart Gereformeerde Christene. Kerke was dus nie amptelik op die vergadering verteenwoordig nie maar die deelnemers was uit die volgende kerke afkomstig:

\author{
Evangelical Presbyterian Church (vroeër die Tsonga Presbyterian \\ Church) \\ Presbyterian Church of Southern Africa \\ Reformed Presbyterian Church of SA \\ United Congregational Church of SA \\ Nederduitse Gereformeerde Kerk in Afrika \\ Nederduitse Gereformeerde Sendingkerk \\ Reformed Church of Africa
}

Buitelandse verteenwoordigers by die vergadering was afkomstig van die United Presbyterian Church in the USA en van die Switserse kerke KEM en DM.

Die Wêreldbond van Gereformeerde Kerke was ook verteenwoordig en het ook 'n finansiële bydrae gelewer vir die stigtingsvergadering. In 'n brief het dr. E. Perret, die algemene sekretaris van die Wêreldbond die organisasie se solidariteit met die vergadering uitgespreek. Die ideaal was dat Swart Gereformeerde Christene uit Suid-Afrika nou met 'n verenigde stem sou kon praat by die vergaderings van die Wêreldbond.

Die Federasie van Switserse Evangeliese Kerke is nie uitgenooi na die vergadering toe nie omdat hulle nog in gesprek was met die NGK oor die dokument Ras, Volk en Nasie. In 'n brief aan die vergadering het die Federasie egter verklaar dat die gesprek met die NGK op 'n dooiepunt beland het en afgebreek is.

Die hoofreferaat is gelewer deur dr. Allan Boesak oor wat dit beteken om Swart en Gereformeerd te wees in Suid-Afrika. Onder "Swart" is verstaan almal wat ly onder die apartheidstelsel in SA. Blankes wat die stelsel verwerp, is dus ook as Swartes gereken. Dr. Boesak is ook verkies as eerste voorsitter van ABRECSA.

Die vraag waarmee die konferensie geworstel het, was of dit nog loon vir Swartmense om Gereformeerd te wees aangesien die gereformeerde tradisie in Suid-Afrika soos verteenwoordig deur die Afrikaanse Kerke so nou vereenselwig word met die onderdrukkende en onmenslike beleid van apartheid.

Die antwoord wat hierop gegee is, is dat swart gereformeerdes 
apartheid as 'n kettery moet verwerp, maar tog solidêr moet bly met die gereformeerde tradisie in sy suiwer vorm. Die verklaring van die konferensie lui dus dat apartheid sonde is en enige morele of teologiese regverdiging daarvan is ' $n$ verdringing van die Evangelie en verraad van die gereformeerde tradisie. Daar word ook besluit dat geen dialoog met die NGK meer gevoer kan word nie solank die NGK nog nie apartheid as sonde verwerp het en sy skuld bely het oor sy aandeel aan die onderdrukking en lyding van Swartmense nie. Hierop kom ons later weer terug.

ABRECSA is dus gevorm om die stem van swart gereformeerde Christene duidelik en onbelemmerd te laat hoor binne die Wêreldbond van Gereformeerde Kerke. By Ottowa het die keuse geval. Die standpunt van ABRECSA is aanvaar en die NGK en NHK is verketter. Voortaan sal ABRECSA gesien word as verteenwoordiger van die ware gereformeerde tradisie in Suidelike Afrika.

In November 1982 het ABRECSA sy tweede konferensie gehou. Dr. A. Boesak het uitgetree as voorsitter maar is aangewys as president. As nuwe voorsitter is ds. A.J. Esterhuizen van die NGSK verkies. Die konferensie onderskryf die handeling van die Wêreldbond om die NGK en die NHK uit die organisasie te skors. Daar word 'n oproep op lede van ABRECSA gedoen om lidmate van die NGK en NHK wat apartheid verwerp in hulle geledere op te neem. Verder word die kerke opgeroep om nie net apartheid te veroordeel nie, maar om dit af te breek in kerk en samelewing. Kerke word opgeroep tot eenwording, maar dan moet dit berus op 'n gesamentlike verwerping van apartheid. Eenheid kan dus nie losgemaak word van sosiale geregtigheid nie.

\section{Evaluering van die standpunte en optrede van die Belydende Kring en ABRECSA}

Beide organisasies voer 'n onwrikbare stryd teen apartheid wat hulle ervaar as ' $n$ beleid wat onderdrukking en lyding vir Swartmense meegebring het. So emosioneel en eksistensieel is hulle by die nadelige en diskriminerende gevolge van die beleid betrokke dat dit geen doel sal dien om te wys op talle positiewe gevolge van die beleid soos desentralisering van nywerhede, uitbreiding van mediese en onderwysgeriewe vir Swartmense, beskerming van swart industriële en handelsbelange, ens. nie.

In hulle kritiek op apartheid het die twee organisasies 'n karikatuur van die NGK en sy bedoelinge geteken. Die NGK staan nie pa vir lyding en onderdrukking wat Swartmense op een of ander wyse binne die strukture van afsonderlike ontwikkeling ervaar het nie om die eenvoudige rede dat hy dit nooit op die oog gehad het nie. In die vyftigerjare het die 
kerk wel gepleit vir ' $n$ totale skeiding van die rasse omdat toe geglo is dat só geregtigheid op sy beste aan almal sou kon geskied. Alleen só sou aan gekleurdes volledige ruimte vir selfontplooiing geskep kon word. Hierdie idealistiese ideaal kon nie verwesenlik word nie en so het wette wat regverdig sou wees in 'n situasie van totale ekonomiese, politieke en geografiese skeiding wel diskriminerend geword in 'n situasie van 'n geïntegreerde samelewing. Die kerk kan verwyt word dat hy te stadig uit sy droom wakker geskrik het en te tydsaam was om sy standpunte by die nuwe situasie aan te pas, maar hy kan nie beskuldig word dat hy ooit lyding, verdrukking of diskriminasie teen enige mense bepleit of goedgepraat het nie. Oor 'n aandeel aan lyding en verdrukking van mense het die NGK nie skuld te bely nie.

As die NGK dan skuld moet bely, dan moet dit wees omdat die gesindheid en optrede van baie van sy lidmate teenoor gekleurdes nog rassisties gekleurd is. Dan moet dit wees omdat baie nog nie die beginsel van oop kerkdeure en die menswaardigheid van alle mense voor God onderskryf nie. Dit is egter uitinge van die sonde waarteen alle kerke te alle tye moet stry. Ook die sogenaamde teologiese regverdiging van afsonderlike ontwikkeling was nooit 'n regverdiging van onderdrukking nie, maar 'n standpunt dat ' $n$ regverdige partisie van die land nie onskriftuurlik is nie. So 'n tipe teologie waarin die skeppingsordeninge sterker beklemtoon word as die herskepping en vernuwing in Christus word vandag nie meer beoefen deur die meerderheid teoloë van die NGK nie.

Wat wel waar is, is dat die Belydende Kring in hulle skerp veroordeling van apartheid die oë van blanke lidmate oopgemaak het vir die wyse waarop Swartmense die beleid ervaar het. Wat ookal die mooi ideale en goeie bedoelinge van die grondleggers van die beleid was, Swartmense het dit ervaar as onregverdig en diskriminerend teen hulle. As daar 'n noodkreet uit die harte van swart Christene uitgaan teen apartheid, kan ons as blanke Christene dit tog seker nie ignoreer nie. As hulle die bedoelinge en motiewe van die NGK so verkeerd verstaan, kan ons dit tog seker nie so laat nie. Die tyd het dus aangebreek dat die NGK hom baie sterk moet uitspreek teen elke vorm van rassisme, onderdrukking en diskriminasie. Hieroor mag daar geen twyfel by swart Christene gelaat word nie. Hierdie uitspraak sal ook baie gou moet kom en die Algemene Sinode van 1986 sal ernstig oorweging moet gee aan die vorm waarin dit moet kom.

Dit moet ongelukkig gestel word dat die Belydende Kring meer tot polarisasie in die NGK bygedra het as tot eenheid. Die gedagte om belydende kringe in die verskillende kerke te organiseer wat later as een veelrassige kerk moet verenig, kan nie anders as om polariserend te werk nie. Hulle metodes om deur groepvorming invloed op moderatuursverkie- 
sings en sinodale besluite uit te oefen, kan nie goedgepraat word nie. Ongelukkig is dit ook so dat die traagheid van die NGK se amptelike vergadering om hulle teen sosiale ongeregtigheid uit te spreek, tot dié soort van optrede aanleiding gee.

Die belangrikste kritiek teen die Belydende Kring is egter nie die gemak waarmee hulle ' $n$ liefdelose karikatuur van die NGK teken nie of die polariserende uitwerking van hulle optrede nie, maar wel die teologiese uitgangspunte waarop hulle denke rus.

Die Belydende Kring het in sy stryd teen die ideologie van apartheid ongelukkig self in ' $n$ ideologiese keurslyf beland. Die ideologie van bevryding het die oogklappe geword wat die beoefening van teologie in die Belydende Kring eensydig begrens. Dit is die hermeneutiese sleutel wat die Bybel ontsluit. Die sentrale boodskap van die Skrif is die bevryding van onderdruktes. Die mensdom word simplisties verdeel in onderdrukkers en onderdruktes, rykes en armes, lydendes en die wat bevry is van lyding. In sy ywer vir "the struggle for total liberation of the oppressed people in South Africa", het die Belydende Kring finaal gekies vir geweld en rewolusie as die wyse waarop die stryd gevoer moet word. Polities lê die simpatie by die ANC en die UDF. Binne hierdie raamwerk van bevryding deur geweld is daar nie plek vir die sentrale Bybelse boodskap van versoening nie. Daarom het die Belydende Kring gekies vir Bevrydingsteologie eerder as vir die Gereformeerde Bybelse teologie wat mens sou kon tipeer as Koninkryksteologie. Trouens die gevaar is groot dat die verskuiwing al hoe meer radikaal sal plaasvind in die rigting van Marxisme. Wie ' $n$ rewolusie wil dryf, mag uitvind dat die Bybel met sy boodskap van versoening en vrede vir hom ' $n$ struikelblok geword het. Die ideologie van Marxisme bied ' $n$ veel beter begronding en regverdiging vir rewolusie as wat selfs bevrydingsteologie kan bied. Die taal binne die Belydende Kring neig dan ook al hoe meer in die rigting van Marxistiese terminologie. Die Suid-Afrikaanse regering is die "racist regime". Die opstandsbewegings is "progressive forces". Die "struggle" is histories gedetermineerd en die uitkoms van die stryd sal 'n oorwinning wees vir die onderdruktes. Daar word gepraat van "a deep existential, almost psychic, experience that the oppressed peoples of South Africa will ultimately triumph". Die stryd (rewolusie) sal eindig in 'n utopie van "a free, united, democratic non-racial society". 2)

Dit is ' $n$ tragedie dat die broeders in die Belydende Kring sowel as Gereformeerde Kerke in die Wêreld wat hom steun nie die radikale waterskeiding tussen Bybelse Koninkryksteologie en radikale kontekstuele Bevrydingsteologie raaksien nie. Natuurlik is bevryding ook ' $n$ sentrale tema in die Skrif. Dit mag egter nooit losgemaak word van die versoening nie. Mense is alleen waarlik vry as hulle vryheid voortspruit uit 'n 
versoening met God en daarom ook versoening met die gelowige medemens. Die mens moet vry word nie om te haat nie, maar om sy medemens lief te hê, nie om te vernietig nie, maar om te bou aan die vrede en geregtigheid van die Koninkryk van God.

Met sy steun vir radikale Bevrydingsteologie is die Belydende Kring ongelukkig besig om die kraal van Gereformeerde Teologie te verlaat. As die NGK in ' $n$ kettery verval het met sy steun vir apartheidsteologie, dan verval die Belydende Kring in net so ' $n$ groot kettery met sy steun vir Bevrydingsteologie.

As die NGK gereformeerde teologie ' $n$ oneer bewys het met ' $n$ teologiese regverdiging vir apartheid, dan bewys die Belydende Kring dit nog 'n groter oneer met sy ondersteuning van rewolusie en geweld as middele waardeur die Koninkryk van God gedien mag word. As die NGK met sy ondersteuning van 'n skeidingsbeleid skuld het aan die lyding van baie mense, sal die Belydende Kring skuld hê aan oneindig meer lyding as daar ' $n$ totale bloedbad in Suid-Afrika sou ontstaan. Die NGK is egter besig om hom te bekeer van apartheidsteologie en om sy lidmate ook op die pad van bekering te probeer lei. Die vraag is of die Belydende Kring hom ook sal bekeer van sy pad van geweld en of hy homself in die afgrond sal laat meesleep in die rewolusie wat hy propageer as enigste manier om apartheid af te breek?

Wat is dan ten slotte die antwoord van die NGK op die eise en aanklagte van die Belydende Kring? In die eerste plek moet die misvattinge van die broeders oor die NGK dringend opgeklaar word. Die NGK moet nom dringend uitspreek teen elke vorm van onderdrukking en diskriminasie. Dit moet in teologiese terme gedoen word sonder dat die kerk verplig word om 'n keuse te maak vir een of ander politieke oplossing. In hierdie opsig moet die NGK weer 'n keer onbevange gaan kyk na die Belhar-belydenis van die NGSK van 1982. Hier is ' $n$ teologiese stuk wat nie die Marxistiese taal adem van sommige uitsprake van die Belydende Kring nie, maar gegrond is op gereformeerde Skrifgebruik. Op die basis van ' $n$ belydenis soos hierdie kan die NGK nog daarin slaag om saam met gekleurde Christene die Koninkrykspad vorentoe te bewandel. Doen hy dit nie, word meer swart Christene dalk uitgedryf in die kraal van die Bevrydingsteologie en selfs in die versoeking gestel om te gryp na die geweld van 'n Marxistiese rewolusie. In dié opsig rus daar dus 'n oneindige swaar verantwoordelikheid op die Algemene Sinode van die NGK. Die Belydende Kring moet ernstig gewaarsku word teen die Bevrydingsteologie wat die sleutel word waarmee hy die Skrif benader. Dit verlei hom om geweld as ' $n$ instrument tot bevryding Bybels te regverdig. Dit is net so ' $n$ verdraaiing van die Skrif as wat die regverdiging van apartheid uit die Skrif ' $n$ verdraaiing is. Dit plaas ' $n$ geweldige 
verantwoordelikheid op sy skouers om dan self die skuld te help dra vir die verskriklike gevolge wat 'n bloedige konfrontasie in die land sal meebring.

Daar is geen ander pad nie as dat swart en wit Christene hulle gesamentlik sal beywer vir die Bybelse beginsels waarop die Koninkryk van God gebou moet word, nl. versoening, geregtigheid, vrede, liefde, menswaardigheid en eenheid van gelowiges. Dit is nie maklik te bereik in 'n sondige en gebroke wêreld nie. Dit word bedreig deur onreg en diskriminasie aan een kant en deur geweld en bloedvergieting aan die ander kant. Gereformeerde Christene, of hulle nou wit of swart is, het geen ander keuse nie as om te stry vir die koms van die Vrederyk van God tot op die dag van die wederkoms.

\section{BIBLIOGRAFIE}

Notules en verslae van die Belydende Kring van NG Kerke.

Notules en verslae van die Alliance of Black Reformed Christians in South Africa.

Verslag Van H.W. Huppenbouer en G. Marier-Genoud aan die Switserse Kerke oor Bund Schwarzer Reformierten Christie in Südafrika.

Belydende Kring Bulletin.

Handelinge van die Algemene Sinode van die Ned. Geref. Kerk in Afrika.

\section{NOTAS}

1) Besluit 1.2.7, Handelinge 1975, 254.

2) Belydende Kring Bulletin, Vol. 3 nr. 8: "The Road Ahead". 